DOI : https://doi.org/10.24843/JFU.2021.v10.i01.p02

pISSN: 2301-7716; eISSN: 2622-4607

Jurnal Farmasi Udayana, Vol 10, No 1, Tahun 2021, 13 - 22

\title{
Produk Inovasi Aromaterapi Berbasis Minyak Atsiri Kemenyan, Kamfer Sumatera Dan Ekaliptus
}

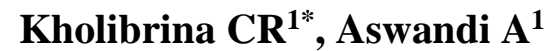 \\ ${ }^{1}$ Balai Penelitian Pengembangan Lingkungan Hidup dan Kehutanan Aek Nauli, \\ Jl. Raya Parapat Km 10,5 Sibaganding Parapat, Simalungun Sumatera Utara, 21174 \\ *E-mail: rizlanicut@yahoo.com \\ Riwayat artikel: Dikirim: 20/11/2020; Diterima: 30/12/2020, Diterbitkan: 1/07/2021
}

\begin{abstract}
The global pandemic Covid-19 encourages peoples to improve their immune system. Both healthy food and regular exercise, good immunity can be achieved from healthy and relaxing mind, including through aromatherapy. This is in line with increasing awareness in holistic and organic medicine. The objectives of study are to develop aromatherapy products based-on sumatran camphor, styrax, and eucalypts essential oils; and to identify consumer preferences for innovation products. A conjoint analysis was operated to determine consumer preferences. The active compounds contained in essential oils combination are including a-pinene, 1.8-cineole, limonene, b-caryophyllene and p-cymene. The combination and presence of similar active compound harmonize aroma with minimal contraindications and produce refreshing and relaxing aromas. The 1.8-cineole is known as anti-fungal, antiviral which offer relief to congested respiratory system, thereby boosts immune system. Moreover, p-cymene has been identified to reduce anxiety, nervousness, and relaxing the mind. Based on conjoint analysis, aroma has the greatest influence on consumer preferences. The most preferred profile is aromatherapy product which soft-refreshing aroma, roll-on package, volume $6 \mathrm{ml}$, at price of Rp 35,000. Aroma is influenced by personal's perceptions, which related to initial recognition of certain scents as olfactory memory.
\end{abstract}

Keywords: aromatherapy, benzoin, camphor, cineole, essential oil, eucalypt

\begin{abstract}
ABSTRAK
Pandemi global Covid-19 mendorong setiap orang berupaya meningkatkan sistem imunitas tubuhnya. Selain melalui makanan sehat dan olah raga teratur, peningkatan imunitas dapat dicapai dari pikiran sehat dan tenang, diantaranya melalui aromaterapi. Hal ini sejalan dengan peningkatan kesadaran terhadap pengobatan holistik dan organik. Penelitian bertujuan untuk mengembangkan produk aromaterapi berbasis minyak atsiri kemenyan, kamfer sumatera dan ekaliptus serta mengetahui preferensi konsumen terhadap produk tersebut. Pendekatan analisis konjoin digunakan untuk mengetahui preferensi konsumen. Kandungan senyawa aktif yang dimiliki oleh kombinasi ketiga minyak atsiri adalah a-pinene, 1.8-cineole, limonene, b-caryophyllene dan p-cymene. Kombinasi ketiga minyak atsiri serta komponen senyawa aktif yang relatif sama membuat harmonisasi aroma dengan kontraindikasi minimal, sehingga menghasilkan aroma dengan efek relaksasi dan menenangkan pikiran. Senyawa 1.8-cineole diketahui bermanfaat sebagai anti-bakteri, anti-virus dan melancarkan sistem pernapasan sehingga meningkatkan sistem kekebalan tubuh. Selanjutnya, senyawa p-cymene diidentifikasi mampu mengurangi kecemasan dan menyegarkan. Berdasarkan analisis conjoint, aroma memiliki pengaruh terbesar terhadap preferensi konsumen. Profil produk aromaterapi yang paling disukai memiliki aroma lembut menyegarkan, paket roll-on, volume $6 \mathrm{ml}$, dengan harga Rp35.000. Hal ini dipengaruhi persepsi pribadi, yang sangat terkait dengan pengenalan awal terhadap aroma tertentu sebagai memori sensorik terhadap aroma.
\end{abstract}

Kata kunci: aromaterapi, cineole, ekaliptus, kamfer, kemenyan, minyak atsiri 
DOI : https://doi.org/10.24843/JFU.2021.v10.i01.p02

pISSN: 2301-7716; eISSN: 2622-4607

Jurnal Farmasi Udayana, Vol 10, No 1, Tahun 2021, 13 - 22

\section{PENDAHULUAN}

Pandemic Covid-19 telah memicu kesadaran global untuk meningkatkan sistem imunitas tubuh. Selain melalui makanan sehat dan berolah raga teratur, peningkatan imunitas dapat juga dicapai dari pikiran sehat dan tenang, diantaranya melalui aromaterapi. Hal ini sejalan dengan peningkatan kesadaran terhadap penggunaan pengobatan holistik dan produk organik. Penggunaan senyawa organik untuk pengobatan juga dipicu kekhawatiran terhadap dampak obat sintesis yang selama ini digunakan (Mank \& Polonska, 2016).

Beberapa minyak atsiri yang potensial sebagai aromaterapi adalah minyak kemenyan, kapur dan ekaliptus. Kemenyan adalah resin berharga dipanen dari pohon kemenyan (Styrax sumatrana) dan telah menjadi komoditas perdagangan utama sejak abad ke-7 (Aswandi \& Kholibrina, 2017; 2020). Ribuan ton resin mentah dikirim ke luar negeri, sedangkan berbagai turunan berupa obat-obatan, parfum, kecantikan, dan bahan pangan bernilai jutaan dolar diimpor setiap tahun. Volume ekspor resin kemenyan mencapai $5.541 \mathrm{~kg}$ dengan nilai US\$ 96.900, sedangkan impor produk akhir berupa produk kecantikan pada tahun 2019 mencapai US\$ 401 juta (Kholibrina \& Aswandi, 2019; Aswandi \& Kholibrina, 2019b).

Bersama dengan kemenyan, resin kamfer telah menjadi magnet bagi bangsabangsa asing ke nusantara dan menebarkan keharuman ke berbagai penjuru dunia (Azhari, 2016). Masyarakat kuno telah menggunakan kamfer sebagai bahan baku obat-obatan dan parfum. Akhir-akhir ini minyak kapur yang berasal dari Dryobalanops banyak dibutuhkan karena diidentifikasi efektif untuk mencairkan darah beku pada pembuluh darah jantung maupun otak manusia (Dharmananda, 2003). Aroma kamfer juga telah lama diidentifikasi memiliki efek relaksasi pikiran (Bhatia et al., 2008; Gusmailina, 2015). Sedangkan minyak ekaliptus telah banyak diaplikasikan untuk berbagai produk kesehatan dan perawatan pribadi.

Saat ini, upaya untuk meningkatkan nilai tambah dari pengolahan minyak atsiri dari hasil hutan tropis semakin berkembang (Ali et al., 2015). Resin kemenyan, kamfer maupun ekaliptus diolah dengan teknik ekstraksi untuk menghasilkan minyak atsiri maupun hidrosol. Namun, produk-produk destilasi ini belum dikembangkan menjadi produk perawatan organik yang inovatif. Meskipun diidentifikasi tersedia beberapa produk sejenis di pasar, produk tersebut masih dihargai sangat mahal.

Dengan mempertimbangkan multidimensi manfaat minyak kemenyan dan kamfer, baik sebagai sumber penghidupan dan perkembangan sosial budaya di Nusantara (Aswandi \& Kholibrina, 2017; 2019a), maka perlu dilakukan peningkatan nilai tambah melalui pengolahan bahan baku minyak atsiri menjadi produk aromaterapi freshener yang ekonomis. Walaupun resin dari pohon endemic hutan tropis, Dryobalanops aromatica ini telah lama dimanfaatkan sebagai bahan pengawet, antibakteri maupun pengharum (Duke, 2015; Bhatia et al., 2008), pemanfaatan kemenyan dan kamfer sebagai aromaterapi dalam kemasan yang praktis belum ditemukan.

Informasi tentang senyawa aromatik resin kemenyan dan kamfer sangat terbatas di masyarakat lokal. Resin yang diasosiasikan dengan aroma dupa yang dibakar dan kurang dimanfaatkan untuk produk-produk bernilai tinggi (Aswandi \& Kholibrina, 2019b; Kholibrina \& Aswandi, 2019). Konsekuensinya, formula aromatiknya belum dieksplorasi, dan potensi harga yang lebih tinggi tidak terpenuhi di pasar lokal (Kholibrina \& Aswandi, 2020; 2019).

Riset ini mengembangkan produk 
DOI : https://doi.org/10.24843/JFU.2021.v10.i01.p02

pISSN: 2301-7716; eISSN: 2622-4607

Jurnal Farmasi Udayana, Vol 10, No 1, Tahun 2021, 13 - 22

inovasi yang memanfaatkan minyak kemenyan, kamfer dan ekaliptus sebagai produk aromaterapi. Berbagai penelitian menunjukkan bahwa ketiga minyak atsiri memiliki kandungan fitofarmaka sebagai antivirus, antiseptik dengan aroma yang menenangkan, memperbaiki sistem saraf, mengembalikan keseimbangan tubuh, serta melancarkan peredaran darah (Ali et al., 2015; Duke, 2015; Gusmailina, 2015; Bhatia et al., 2008; (Sharif et al., 2016). Dengan berbagai manfaat tersebut, inovasi produk aromaterapi dinilai prospektif sebagai produk kesehatan.

Penelitian ini bertujuan untuk mengembangkan produk aromaterapi berbasis minyak atsiri kemenyan, kamfer sumatera dan ekaliptus serta mengetahui preferensi konsumen terhadap produkaromaterapi tersebut. Pengembangan produk inovasi diharapkan meningkatkan nilai tambah produk hasil hutan bukan kayu serta mengurangi ketergantungan impor kesehatan berbasis kemenyan dan kamfer. Informasi mengenai beberapa atribut penting yang menjadi pertimbangan konsumen serta bagaimana kombinasi atribut produk aromaterapi yang memenuhi keinginan konsumen diharapkan dapat mendorong perkembangan produk inovasi dalam negeri.

\section{BAHAN DAN METODE}

\section{Bahan dan Alat}

Bahan utama yang digunakan adalah minyak atsiri kamfer, kemenyan, dan ekaliptus. Selain itu juga diperlukan minyak pembawa (carrier oils), dan botol kemasan 10; 6; dan $3 \mathrm{~mL}$ dalam bentuk roll-on maupun spray. Peralatan yang digunakan adalah sebuah steam distillatory, rotary evaporator, beberapa gelas ukur, plancard, perangkat komputer dengan SPSS 14 for window dan lainnya.

\section{Metode}

\section{Ekstraksi Minyak Atsiri}

Minyak atsiri dihasilkan dengan dua cara yakni ekstraksi pelarut dan destilasi. Pelarut alkohol digunakan untuk ekstraksi minyak kemenyan dengan perbandingan 1:1 (b/b). Selanjutnya pelarut dikeluarkan dengan rotary evaporator. Metode ini telah diterapkan dalam berbagai penelitian terkait (Aswandi \& Kholibrina, 2020). Minyak kamfer dan ekaliptus diekstaksi dari daun menggunakan peralatan destilator uap. Ketiga minyak atsiri yang diperoleh merupakan bahan utama yang digunakan sebagai campuran produk aromaterapi.

Formulasi Aromaterapi

Produk aromaterapi terdiri dari satu atau kombinasi berbagai minyak atsiri dengan konsentrasi yang berbeda-beda. Dalam riset ini produk aromaterapi dikembangkan dengan memanfaatkan minyak atsiri kemenyan sebagai base-note yang dikombinasikan dengan minyak kamfer, dan ekaliptus. Kombinasi berbagai konsentrasi minyak atsiri yang digunakan ditunjukkan pada Tabel 1.

Sesuai dengan formulasi yang diujikan, masing-masing minyak atsiri beserta minyak carrier dituangkan pada gelas ukur dengan volume total $35 \mathrm{ml}$. selanjutnya, gelas dikocok hingga campuran minyak atsiri homogen.

Tabel 1. Bahan dan jumlah yang digunakan dalam berbagai formulasi

\begin{tabular}{cccccc}
\hline \multirow{2}{*}{ Formula } & \multicolumn{3}{c}{ Volume minyak $(\mathbf{m L})(\%)$} & Total \\
\cline { 2 - 5 } & Kemenyan & Kamfer & Ekaliptus & Carrier oil & 35 ml \\
\hline $\mathbf{1}$ & $5(14,3)$ & $5(14,3)$ & $10(28,6)$ & $15(42,9)$ & $35(100)$ \\
$\mathbf{2}$ & $5(14,3)$ & $10(28,6)$ & $5(14,3)$ & $15(42,9)$ & $35(100)$ \\
$\mathbf{3}$ & $10(28,6)$ & $5(14,3)$ & $5(14,3)$ & $15(42,9)$ & $35(100)$ \\
$\mathbf{4}$ & $0(0)$ & $10(28,6)$ & $10(28,6)$ & $15(42,9)$ & $35(100)$ \\
$\mathbf{5}$ & $10(28,6)$ & $10(28,6)$ & $0(0)$ & $15(42,9)$ & $35(100)$ \\
$\mathbf{6}$ & $10(28,6)$ & $0(0)$ & $10(28,6)$ & $15(42,9)$ & $35(100)$ \\
\hline
\end{tabular}


DOI : https://doi.org/10.24843/JFU.2021.v10.i01.p02

pISSN: 2301-7716; eISSN: 2622-4607

Jurnal Farmasi Udayana, Vol 10, No 1, Tahun 2021, 13 - 22

\section{Evaluasi Produk Aromaterapi}

Untuk mengevaluasi penerimaan konsumen terhadap produk aromaterapi, survei anonim dilakukan. Empat puluh responden dipilih untuk ditanyai tentang ekspresi produk aromaterapi yang diuji (sensasi setelah menghirup, sensitivitas, aroma yang menenangkan, aroma yang menyegarkan, keinginan untuk terus menggunakan). Nilai tiap profil formulasi aromaterapi ditentukan menurut skala likert dengan tiga pilihan skala yakni tinggi (pleasant); sedang (moderate); rendah (untolerable). Semua responden yang menggunakan minyak atsiri minimal dua hari berturut-turut.

Pendekatan analisis konjoin digunakan untuk menentukan preferensi konsumen terhadap produk-produk yang diujikan. Pendekatan ini juga diterapkan dalam beberapa penelitian sebelumnya (Kholibrina \& Aswandi, 2020; Dwi \& Rustam, 2014). Penilaian proferensi konsumen dimulai dengan desain ortogonal menghasilkan file data yang berisi desain efek utama ortogonal yang memungkinkan pengujian statistik beberapa faktor tanpa menguji setiap kombinasi level faktor. Desain ini ditampilkan dengan prosedur Desain Tampilan (SPSS Inc., 2004).

Studi ini menguji pengaruh empat faktor terhadap preferensi konsumen yaitu aroma, kemasan, volume, dan harga. Terdapat enam tingkat faktor untuk aroma; dua tingkat kemasan (roll on, spray); tiga tingkat volume ( $3 \mathrm{ml}, 6 \mathrm{ml}$ dan $10 \mathrm{ml})$; dan tiga tingkatan harga (Rp20.000, Rp35.000, Rp50.000). Tabel 2 menampilkan variabel yang digunakan dengan; label dan nilainya.

Tabel 2. Variabel kesukaan konsumen terhadap produk aromaterapi

\begin{tabular}{ccc}
\hline Faktor & Nilai & Label \\
\hline Aroma & $1,2,3,4,5,6$ & $\mathrm{~F} 1, \mathrm{~F} 2, \mathrm{~F} 3, \mathrm{~F} 4, \mathrm{~F} 5, \mathrm{~F} 6$ \\
Paket & 1,2 & roll_on, spray \\
Volume & $1,2,3$ & $3 \mathrm{ml}, 6 \mathrm{ml}, 10 \mathrm{~mL}$ \\
Harga & $1,2,3$ & $\mathrm{Rp} 20.000, \mathrm{Rp} 35.000, \mathrm{Rp} 50.000$ \\
\hline
\end{tabular}

Langkah selanjutnya adalah membuat kombinasi level faktor yang disajikan sebagai profil produk untuk setiap subjek. Prosedur desain generasiortogonal menciptakan larik ortogonal, yang disebut sebagai desain orthogonal (SPSS Inc., 2004). Setelah desain ortogonal dibuat, profil setiap produk disusun untuk dinilai oleh responden. Setelah desain ortogonal dihasilkan, preferensi konsumen untuk setiap profil produk diperoleh melalui wawancara terhadap 40 responden yang menggunakan produk aromaterapi. Responden diminta untuk menentukan peringkat 27 profil produk dari yang paling disukai hingga paling tidak disukai.

\section{HASIL}

Sejak satu dekade terakhir, konsumen menjadi lebih selektif terhadap produk perawatan pribadi yang mereka gunakan. Meskipun banyak produk serupa tersedia, produk berkualitas tinggi dan harga bersaing akan memenuhi kepuasan pelanggan dan meningkatkan loyalitas terhadap produk tersebut. Produk aromaterapi dalam penelitian ini adalah inovasi riset yang mengeksplorasi formulasi wewangian minyak kamfer dan kemenyan, dikenal sebagai resin dewa dan digunakan oleh hampir semua agama dan kepercayaan.

Untuk mengevaluasi penerimaan konsumen terhadap produk aromaterapi, empat puluh responden dipilih untuk 
DOI : https://doi.org/10.24843/JFU.2021.v10.i01.p02

pISSN: 2301-7716; eISSN: 2622-4607

Jurnal Farmasi Udayana, Vol 10, No 1, Tahun 2021, 13 - 22

ditanyai tentang ekspresi mereka terhadap produk aromaterapi yang diuji (sensasi setelah menghirup, sensitivitas, aroma yang menenangkan dan menyegarkan, keinginan untuk terus menggunakan). Respon responden terhadap setiap profil produk aromaterapi ditunjukkan pada Tabel 3.

Tabel 3. Nilai ekspresi responden terhadap setiap profil formulasi aromaterapi

\begin{tabular}{|c|c|c|c|c|c|c|c|c|c|c|c|c|}
\hline \multirow{2}{*}{$\begin{array}{c}\text { Formula } \\
\text { si }\end{array}$} & \multicolumn{3}{|c|}{$\begin{array}{c}\text { Sensasi setelah } \\
\text { menghirup }\end{array}$} & \multicolumn{3}{|c|}{ Sensitivitas } & \multicolumn{3}{|c|}{ Aroma } & \multicolumn{3}{|c|}{$\begin{array}{c}\text { Keinginan untuk } \\
\text { terus menggunakan }\end{array}$} \\
\hline & $\begin{array}{l}\text { Tinggi } \\
\end{array}$ & Sedang & Rendah & Tinggi & Sedang & Rendah & Tinggi & Sedang & Rendah & Tinggi & Sedang & Rendah \\
\hline 1 & 37,5 & 40,0 & 22,5 & 27,5 & 42,5 & 30,0 & 37,5 & 40,0 & 22,5 & 35,0 & 42,5 & 22,5 \\
\hline 2 & 45,0 & 40,0 & 15,0 & 35,0 & 40,0 & 25,0 & 45,0 & 37,5 & 17,5 & 42,5 & 37,5 & 20,0 \\
\hline 3 & 40,0 & 37,5 & 22,5 & 37,5 & 37,5 & 25,0 & 40,0 & 40,0 & 20,0 & 40,0 & 40,0 & 20,0 \\
\hline 4 & 35,0 & 37,5 & 27,5 & 25,0 & 40,0 & 35,0 & 35,0 & 40,0 & 25,0 & 35,0 & 35,0 & 30,0 \\
\hline 6 & 37,5 & 40,0 & 22,5 & 27,5 & 42,5 & 30,0 & 35,0 & 42,5 & 22,5 & 35,0 & 37,5 & 27,5 \\
\hline $\begin{array}{l}\text { Rata- } \\
\text { rata }\end{array}$ & 39,0 & 39,0 & 22,0 & 30,5 & 40,5 & 29,0 & 38,5 & 40,0 & 21,5 & 37,5 & 38,5 & 24,0 \\
\hline
\end{tabular}

Empat puluh kuesioner divalidasi, rata-rata $76,0 \%$ responden menyatakan kesediaan mereka untuk terus menggunakan produk aromaterapi. Selanjutnya sebanyak $37,5 \%$ responden menyatakan tingkat kepuasan tinggi dan $38,5 \%$ memiliki kepuasan sedang. Hal ini menunjukkan sebagian besar responden memiliki preferensi menyenangkan (pleasant) terhadap sensasi kesegaran dan relaksasi setelah menghirup aromaterapi, tingkat sensitivitas yang sesuai untuk indera penciuman, serta aroma yang menyegarkan.

\section{Biaya Produksi}

Sebuah studi sederhana telah dilakukan untuk memperkirakan biaya yang terkait dengan produksi produk aromaterapi. Tabel 4 menunjukkan biaya bahan baku komersial yang digunakan untuk memproduksi $350 \mathrm{ml}$ menggunakan formulasi 2. Dari data tersebut diperkirakan biaya produksi sekitar $\mathrm{Rp}$ 1.020.850 atau sekitar Rp 2.916/ml dengan belum memperhitungkan upah kerja.

Tabel 4. Biaya produksi produk aromaterapi

\begin{tabular}{ccccc}
\hline Minyak atsiri & $\begin{array}{c}\text { Paket } \\
(\mathbf{m l})\end{array}$ & $\begin{array}{c}\text { Unit Harga } \\
(\mathbf{R p})\end{array}$ & $\begin{array}{c}\text { Jumlah } \\
\text { digunakan }(\mathbf{m l})\end{array}$ & $\begin{array}{c}\text { Biaya real } \\
(\mathbf{R p})\end{array}$ \\
\hline Carrier oil \#1 & 1.000 & 57.000 & 50 & 2.850 \\
Carrier oil \#2 & 100 & 208.000 & 100 & 208.000 \\
Minyak kemenyan & 10 & 72.000 & 50 & 360.000 \\
Minyak kamfer & 100 & 250.000 & 100 & 250.000 \\
Minyak ekaliptus & 50 & 200.000 & 50 & 200.000 \\
Total & & & 350 & 1.020 .850 \\
\hline
\end{tabular}

Akhir-akhir ini aromaterapi telah menjadi mode, namun pada umumnya produk yang digunakan dianggap sebagai barang berkualitas unggul, diproduksi dengan bahan baku yang bagus, sehingga dihargai tinggi. Pada situs daring, harga aromaterapi kamfer mencapai US\$ 16,22 untuk kemasan $10 \mathrm{ml}$. Sedangkan produk inovasi ini hanya dijual dengan harga Rp 50.000 untuk kemasan yang sama dengan harga produksi hanya Rp 30.000.

\section{Preferensi Konsumen}

Preferensi konsumen terhadap produk aromaterapi yang diuji secara kuantitatif dihitung dari nilai utilitas (utility score) dan kepentingan relatif. Nilai utilitas 
DOI : https://doi.org/10.24843/JFU.2021.v10.i01.p02

pISSN: 2301-7716; eISSN: 2622-4607

Jurnal Farmasi Udayana, Vol 10, No 1, Tahun 2021, 13 - 22

ini merupakan skor numerik yang mengukur seberapa besar setiap fiturproduk memengaruhi keputusan pelanggan untuk suatu pilihan (SPSS Inc., 2004). Tabel 5 menunjukkan skor utilitas untuk keempat faktor yang diujikan.

Nilai utilitas yang lebih tinggi menunjukkan preferensi responden yang lebih besar terhadap suatu profil produk aromatepi. Berdasarkan Tabel 5, nilai utilitas tertinggi ditunjukkan oleh faktor aroma dari Formula $2(8,573)$. Hal ini menggambarkan preferensi terbesar responden terhadap sensasi aroma suatu produk aromaterapi setelah dihirup. Aroma Formula 2 menghasilkan sensasi wangi yang lembut, manis, namun penyegarkan dengan efek relaksasi. Sebaliknya, nilai utilitas terendah ditunjukkan oleh aroma Formula 4. Preferensi terendah varian aromaterapi ini dikarenakan sensasi aroma yang menyengat, tajam dan menusuk hidup akibat konsentrasi minyak kamfer dan ekaliptus yang tinggi serta ketiadaan minyak kemenyan yang beraroma lebih lembut dalam komposisinya.

Tabel 5. Nilai utilitas produk aromaterapi

\begin{tabular}{|c|c|c|c|}
\hline \multicolumn{2}{|c|}{ Faktor } & \multirow{2}{*}{$\begin{array}{r}\text { Nilai Utilitas } \\
3,285\end{array}$} & \multirow{2}{*}{$\begin{array}{c}\text { Galat baku } \\
0,691\end{array}$} \\
\hline Aroma & Formula 1 & & \\
\hline & Formula 2 & 8,573 & 0,691 \\
\hline & Formula 3 & 8,164 & 0,691 \\
\hline & Formula 4 & $-8,018$ & 0,909 \\
\hline & Formula 5 & $-5,775$ & 0,909 \\
\hline & Formula 6 & $-6,230$ & 0,909 \\
\hline \multirow[t]{2}{*}{ Paket } & roll_on & $-0,106$ & 0,722 \\
\hline & spray & $-0,212$ & 1,444 \\
\hline \multirow[t]{3}{*}{ Volume } & $3 \mathrm{ml}$ & 2,091 & 0,417 \\
\hline & $6 \mathrm{ml}$ & 4,182 & 0,834 \\
\hline & $10 \mathrm{ml}$ & 6,273 & 1,251 \\
\hline \multirow[t]{3}{*}{ Harga } & Rp 20.000 & $-3,556$ & 0,417 \\
\hline & Rp 35.000 & $-7,111$ & 0,834 \\
\hline & Rp 50.000 & $-10,667$ & 1,251 \\
\hline \multicolumn{2}{|c|}{ (Konstanta) } & 5,171 & 14,846 \\
\hline
\end{tabular}

Tabel 5 menunjukkan bahwa sebagian besar responden lebih menyukai produk aromaterapi yang dikemas dalam bentuk roll-on dibandingkan spray. Kemudahan pengaturan volume minyak atasiri yang dihirup pada paket roll-on lebih disukai konsumen. Lepasnya senyawa volatil yang lebih banyak dalam suatu waktu dalam penggunaan paket spray mengakibatkan sensasi aroma yang lebih menyengat diterima sensor penciuman. Dengan kemasan yang berukuran lebih besar, volume $10 \mathrm{ml}$ lebih disukai karena ukuran tersebut masih dinilai ergonomis dan mampu menampung isi yang cukup untuk penggunaan aromaterapi secara intensif.
Secara keseluruhan preferensi konsumen tertinggi adalah aroma lembut namun menyegarkan yang dihasilkan Formula 2, paket berupa roll on, volume sedang $6 \mathrm{ml}$, dengan harga Rp 35.000 . Seperti yang diharapkan, Tabel 5 juga menunjukkan terdapat hubungan terbalik antara harga dan utilitas. Dalam hal ini harga yang lebih tinggi akan mendorong utilitas yang lebih rendah. Kisaran nilai utilitas (tertinggi ke terendah) untuk setiap faktor memberikan ukuran seberapa penting faktor tersebut bagi preferensi konsumen secara keseluruhan. Faktorfaktor dengan rentang utilitas yang lebih besar memainkan peran yang lebih signifikan dibandingkan faktor-faktor dengan rentang utilitas yang lebih kecil 
DOI : https://doi.org/10.24843/JFU.2021.v10.i01.p02

pISSN: 2301-7716; eISSN: 2622-4607

Jurnal Farmasi Udayana, Vol 10, No 1, Tahun 2021, 13 - 22

(SPSS Inc., 2004).

Selanjutnya Tabel 6 menunjukkan nilai kepentingan untuk setiap faktor produk aromaterapi. Hasil penelitian menunjukkan bahwa aroma (nilai kepentingan 60,02) memiliki pengaruh tertinggi terhadap preferensi konsumen secara keseluruhan.

Tabel 6. Kepentingan relatif faktor produk aromaterapi

\begin{tabular}{cr}
\hline Faktor & Nilai \\
\hline Aroma & 60,02 \\
Paket & 1,29 \\
Volume & 14,30 \\
Harga & 24,39 \\
\hline
\end{tabular}

\section{PEMBAHASAN}

Setelah menghirup berbagai formulasi aromaterapi yang diujikan, sebanyak $45 \%$ responden memberikan nilai tertinggi terhadap sensasi menyegarkan dan relaksasi. Sensasi ini dihasilkan oleh Formula 2 (Tabel 3). Efek relaksasi dan menyegarkan dengan wangi citrus berasal dari senyawa $p$-cymene dan limonene. Pada suhu kamar, kedua senyawa yang dikandung minyak ekaliptus dan kamfer mudah menguap dengan aroma yang cukup menyengat, namun dicampur dengan minyak kemenyan yang beraroma lebih lembut, kombinasi aroma yang dihasilkan lebih menyenangkan. Senyawa limonene juga banyak ditemukan pada buah jeruk atau lemon diketahui dapat menghilangkan kecemasan dan depresi, serta melawan infeksi bakteri dan mengobati bisul. Sedangkan senyawa $p$ cymene diidentifikasi dapat mengurangi kecemasan, menyegarkan serta meningkatkan libido (Duke, 2015; Bhatia et al., 2008).

Aroma khas seperti terpentin namun lebih lembut juga tercium sebagai sensasi awal. Aroma ini berasal dari a-pinene dan b-pinene yang terdapat pada ketiga minyak atsiri (Duke, 2015; Bhatia et al., 2008). Senyawa tidak berwarna yang larut dalam alkohol ini memiliki bau kayu pinus segar dan diidentifikasi membantu mengurangi peradangan, membunuh bakteri, meningkatkan fungsi kognitif, dan mengurangi kecemasan. Namun, pada konsentrasi yang lebih tinggi, komposisi senyawa a-pinene, b-pinene, limonene dan p-cymene menghasilkan aroma menyengat dan sensasi menusuk hidung ketika dihirup.

Sensasi pertama ketika menghirung produk aromaterapi berasal dari aroma minyak atsiri yang menjadi top-note dalam hal ini adalah senyawa volatile dari minyak ekaliptus dan kamfer. Dengan kandungan molekul yang lebih ringan, senyawasenyawa yang terkandung pada kedua minyak atsiri ini pertama kali ditangkap oleh sensor penciuman, sedangkan minyak atsiri yang menjadi basis yakni minyak kemenyan melepaskan aroma pada tahap berikutnya setelah 10-15 menit kemudian.

Selanjutnya, rasa hangat yang pedas dan menusuk hidung dengan aroma yang mirip dengan kayu manis dan cengkeh berasal dari senyawa $b$-caryophyllene dan eugenol yang dikandung minyak kamfer dan kemenyan. Berkat kemampuannya mengikat reseptor CB2 pada sistem endocannabinoid, $\quad b$-caryophyllene memiliki efek anti-inflamasi dan antioksidan yang kuat sehingga membantu meredakan nyeri dan kecemasan, kejang, dan mengurangi kolesterol (Johnson et al., 2020).

Setelah beberapa menit, aroma balsamic seperti madu yang pedas namun 
DOI : https://doi.org/10.24843/JFU.2021.v10.i01.p02

pISSN: 2301-7716; eISSN: 2622-4607

Jurnal Farmasi Udayana, Vol 10, No 1, Tahun 2021, 13 - 22

manis menyenangkan juga tercium. Aroma ini dihasilkan oleh senyawa benzyl cinnamate, cinnamic acid, styrene dan benzoic acid yang terdapat pada minyak kemenyan (Sharif et al., 2016). Selain digunakan pada industri parfum dan perasa makanan, benzoic acid juga digunakan sebagai pengawet organik dan anti-jamur.

Setelah impresi aroma awal yang menyengat dan menyegarkan, kandungan linalool yang terdapat pada minyak ekaliptus dan kamfer akan menghasilkan aroma bunga yang lembut. Sebuah studi mengungkap senyawa ini menurunkan perilaku agresif pada tikus (Linck et al., 2010).

Kombinasi ketiga minyak atsiri ini dengan komposisi yang tepat serta adanya komponen senyawa aktif yang sama membuat harmonisasi aroma dengan kontraindikasi minimal, sehingga aroma yang dihasilkan memiliki efek relaksasi dan menenangkan pikiran. Berdasarkan perbandingan respon responden terhadap aroma berbagai formulasi, kombinasi minyak atsiri berdasarkan Formula 2 menghasilkan aroma yang lebih lembut.

Sensasi aroma lembut tersebut berasal dari senyawa 1,8-cineole yang memiliki aroma mirip minyak esensial rosemary (Sharif et al., 2016). Senyawa ini terdapat pada ketiga minyak atsiri. Senyawa 1,8-cineole diketahui bermanfaat sebagai anti-bakteri, anti-jamur dan antivirus yang potensial melancarkan sistem pernapasan dengan membersihkan paruparu sehingga meningkatkan sirkulasi darah serta sistem kekebalan tubuh (Duke, 2015; Bhatia et al., 2008; Dharmananda, 2003)). Aroma wangi yang tercium seperti wangi manis khas almond, sedikit berbau tajam, dan bermotif bunga diidentifikasi berasal dari allyl benzoate dan benzaldehyde yang dikandung minyak kemenyan.

$$
\text { Mengingat wewangian yang }
$$
digunakan dalam penelitian ini lebih menyegarkan, lebih mencolok atau lebih manis, maka respon responden terhadap kombinasi minyak atsiri yang dapat diuji sangat mempengaruhi persepsi responden. Hal ini menunjukkan terdapat perbedaan yang signifikan pada preferensi konsumen terhadap profil produk yang mengandung aroma yang paling diinginkan dengan yang paling tidak disukai. Perbedaan respon ini dikarenakan preferensi setiap pribadi untuk aroma tertentu bersifat pribadi dan unik (Ali et al., 2015; Gonçalves et al., 2013).

Dalam hal ini, aroma telah dipahami sebagai subjek yang kompleks karena interpretasinya sangat bervariasi menurut konteks yang sangat dipengaruhi oleh berbagai faktor internal maupun eksternal. Secara internal, preferensi responden terhadap aroma sangat dipengaruhi oleh pengenalan awal terhadap aroma tertentu sebagai interpretasi pribadinya, yang sangat berkaitan dengan memori sensorik setiap orang terhadap aroma (Ali et al., 2015; (Gonçalves et al., 2013; Milotic, 2003).

Hasil juga menunjukkan bahwa paket dan volume memiliki nilai kepentingan terendah (masing-masing 1,29 dan 14,30). Hal ini menunjukan peran kedua faktor tersebut yang kecil dalam penentukan preferensi konsumen secara keseluruhan. Harga memiliki nilai kepentingan relatif yang cukup tinggi $(24,39)$, namun tidak sepenting aroma. Hal ini ditengarai karena kisaran harga yang sempit. Selain itu, konsumen juga menilai bahwa harga yang ditawarkan masih relatif terjangkau untuk produk yang berkualitas jika dibandingkan produk aromaterapi sejenis lainnya.

Pada akhirnya, temuan studi menunjukkan bahwa pengujian produk merupakan hal penting sebelum diluncurkan ke pasar. Terlepas dari seberapa efektif dan berkhasiat suatu produk aromaterapi, jika konsumen tidak menyukai aromanya, yang dimungkinkan akibat perbedaan persepsi terhadap produk 
DOI : https://doi.org/10.24843/JFU.2021.v10.i01.p02

pISSN: 2301-7716; eISSN: 2622-4607

Jurnal Farmasi Udayana, Vol 10, No 1, Tahun 2021, 13 - 22

tersebut, maka dapat diprediksi bahwa produk tersebut akan mengalami kegagalan di dalam pemasarannya.

\section{KESIMPULAN}

Produk-produk aromaterapi dikembangkan dengan memanfaatkan minyak atsiri kemenyan sebagai base-note yang dikombinasikan dengan minyak kamfer dan ekaliptus. Kombinasi ketiga minyak atsiri ini serta adanya komponen senyawa aktif yang sama membuat harmonisasi aroma dengan kontraindikasi minimal, sehingga aroma yang dihasilkan memiliki efek relaksasi dan menenangkan pikiran. Berdasarkan analisis konjoin, varian aroma memiliki pengaruh paling besar terhadap preferensi konsumen secara keseluruhan. Preferensi konsumen tertinggi adalah produk aromaterapi dengan profil aroma lembut namun menyegarkan, paket roll-on, volume sedang $6 \mathrm{ml}$, dengan harga $\mathrm{Rp}$ 35.000. Hal ini dipengaruhi persepsi pribadi responden, yang sangat terkait dengan pengenalan awal terhadap aroma tertentu sebagai memori sensorik terhadap aroma.

\section{UCAPAN TERIMAKASIH}

Ucapan terimakasih disampaikan kepada Badan Litbang dan Inovasi KLHK, SEAMEO Biotrop yang mendukung penelitian dan penulisan karya tulis ilmiah.

\section{DAFTAR PUSTAKA}

Ali, B., Al-Wabel, N. A., Shams, S., Ahamad, A., Khan, S. A., \& Anwar, F. (2015). Essential oils used in aromatherapy: A systemic review. Asian Pacific Journal of Tropical Biomedicine, 5(8). https://doi.org/10.1016/j.apjtb.2015.0 5.007

Aswandi, A., \& Kholibrina, C. R. (2017). Pemulihan Ekosistem Danau Toba. Bina Media Perintis.
Aswandi, A., \& Kholibrina, C. R. (2019a). Kapur (Dryobalanops aromatica): Sebaran, Produktivitas dan Teknik Silvikultur Pohon Penghasil Kamfer. In N. Mindawati \& Yulianti (Eds.), Bunga Rampai Perakitan Teknologi Jenis Tanaman Hutan Unggulan Lokal Daerah Untuk Peningkatan Nilai Tambah (pp. 73-98). IPB Press. Aswandi, A., \& Kholibrina, C. R. (2019b). Tobarium: Parfum Kemenyan Danau Toba. Forest Digest Magazine. https://www.forestdigest.com/detail/3 92/tobarium-parfum-kemenyandanau-toba

Aswandi, A., \& Kholibrina, C. R. (2020). The grading classification for Styrax sumatrana resins based on physico chemical characteristics using twostep cluster analysis. IOP Conference Series: Materials Science and Engineering, 935, 012013. https://doi.org/10.1088/1757899X/935/1/012013

Azhari, I. (2016). Perihal Kapur Barus dan Kemenyan dalam Sumber danTulisan Sejarah. In I. Azhari \& A. Aswandi (Eds.), Jejak Kapur Barus dan Kemenyan Sumatera Utara dalam Peradaban Dunia. Pusat Studi Sejarah UNIMED.

Bhatia, S. P., Letizia, C. S., \& Api, A. M. (2008). Fragrance material review on borneol. Food and Chemical Toxicology, 46(11). https://doi.org/10.1016/j.fct.2008.06. 031

Dharmananda, S. (2003). Dryobalanops for medicine. Institute for Traditional Medicine. Portland-Oregon

Duke, S. (2015). Plants containing Borneol. In Phytochemical and Ethnobotanical Databases. PortlandOregon

Dwi, C., \& Rustam, S. (2014). Consumer preference analysis on choosing minimarket with convenience store 
DOI : https://doi.org/10.24843/JFU.2021.v10.i01.p02

pISSN: 2301-7716; eISSN: 2622-4607

Jurnal Farmasi Udayana, Vol 10, No 1, Tahun 2021, 13 - 22

concept in Bandung (Study in Circle K , Indomaret and Alfamart in 2014). 200-207.

Gonçalves, G. M. S., Srebernich, S. M., Vercelino, B. G., \& Zampieri, B. M. (2013). Influence of the presence and type of fragrance on the sensory perception of cosmetic formulations. Brazilian Archives of Biology and Technology, 56(2). https://doi.org/10.1590/S151689132013000200005

Gusmailina, G. (2015, April 1). Borneol potensi minyak atsiri masa depan. https://doi.org/10.13057/psnmbi/m01 0215

Johnson, S. A., Rodriguez, D., \& Allred, K. (2020). A Systematic Review of Essential Oils and the Endocannabinoid System: A Connection Worthy of Further Exploration. Evidence-Based Complementary and Alternative Medicine, 2020. https://doi.org/10.1155/2020/803530 1

Kholibrina, C. R., \& Aswandi, A. (2019). Inovasi parfum kemenyan untuk peningkatan nilai tambah resin kemenyan toba. In N. Mindawati \& Yulianti (Eds.), Bunga Rampai Perakitan Teknologi Jenis Tanaman Hutan Unggulan Lokal Daerah Untuk Peningkatan Nilai Tambah. IPB Press.

Kholibrina, C. R., \& Aswandi, A. (2020). The consumer preferences for new styrax based perfume products using a conjoint analysis approach. IOP Conference Series: Materials Science and Engineering, 935, 012016. https://doi.org/10.1088/1757899X/935/1/012016

Linck, V. M., da Silva, A. L., Figueiró, M., Caramão, E. B., Moreno, P. R. H., \& Elisabetsky, E. (2010). Effects of inhaled Linalool in anxiety, social interaction and aggressive behavior in mice. Phytomedicine, 17(8-9). https://doi.org/10.1016/j.phymed.200 9.10.002

Mank, V., \& Polonska, T. (2016). Use of natural oils as bioactive ingredients of cosmetic products. Ukrainian Food Journal, $5(2)$. https://doi.org/10.24263/2304-974X2016-5-2-7

Milotic, D. (2003). The impact of fragrance on consumer choice. Journal of Consumer Behaviour, 3(2). https://doi.org/10.1002/cb.131

Sharif, A., Nawaz, H., Rafia, R., Ayesha, M., \& Rashid, U. (2016). A review on bioactive potential of Benzoin resin. International Journal of Chemical and Biochemical Sciences, 10, 106110.

SPSS Inc. (2004). SPSS conjoint 14.0. In International Journal of HumanComputer Studies (Vol. 71, Issues 78). http://www.docs.is.ed.ac.uk/skills/do cuments/3639/SPSSConjoint14.0.pdf 